\title{
Treatment of Iraqi Municipal Wastewater by up-flow Anaerobic Sludge Blanket Reactor UASB
}

\author{
Khairi R. Kalash ${ }^{a^{*}}{ }^{\text {, Majid A. Dixon }}{ }^{b}$, Hussein IR. Sultan ${ }^{c}, \operatorname{Raad}$ A. Ali ${ }^{\text {d }}$ \\ ${ }^{\text {a }}$ Environment and Water Directorate, Ministry of Science and Technology, Baghdad, Iraq \\ khairirs@yahoo.com \\ ${ }^{\mathrm{b}}$ Environment and Water Directorate, Ministry of Science and Technology, Baghdad, Iraq \\ ${ }^{\mathrm{c}}$ Environment and Water Directorate, Ministry of Science and Technology, Baghdad, Iraq \\ ${ }^{\mathrm{d}}$ Environment and Water Directorate, Ministry of Science and Technology, Baghdad, Iraq \\ *Corresponding author.
}

Submitted: 10/09/2019

Accepted: 26/12/2019

Published: 25/01/2021

K E Y W O R D S

Anaerobic, Sludge

Blanket, wastewater, digestion, UASB reactor.

\section{A B S T R A C T}

In this work, the Upflow Anaerobic Sludge Blanket "UASB" reactor treated effluent wastewater to investigate the process performance on a pilot plant scale. Municipal wastewater at high and medium strength with different organic load rate OLR (0.6-9) $\mathrm{kg} \mathrm{COD} \mathrm{m}^{-3} \mathrm{day}^{-1}$ with the flow of $20 \mathrm{l} / \mathrm{h}$, up-flow velocity $0.4 \mathrm{~m} / \mathrm{h}$, hydraulic retention time $H R T 9 \mathrm{~h}$ at a temperature of $\left(20-30{ }^{\circ} \mathrm{C}\right)$ was evaluated. The wastewater concentration, including TSS, COD was measured, and the removal efficiencies of chemical oxygen demand (COD) and total suspended solid TSS were calculated and summarized as 45-85\% and 70-75\%, respectively, depending on organic load rate OLR. Effluent volatile fatty acids VFA was measured, and the results were in the range between $12-90 \mathrm{mg} / \mathrm{L}$ depending on OLR with a slight change in $\mathrm{pH}$ (8.3-8.4), which means the conversion of COD to methane and increase ammonia concentration.

How to cite this article: Khairi R. Kalash, Majid A. Dixon, Hussein IR. Sultan and Raad A. Ali "Treatment of Iraqi Municipal

Wastewater by upflow Anaerobic Sludge Blanket Reactor UASB," Engineering and Technology Journal, Vol. 39, Part A, No. 01, pp. 130-136, 2021.

DOI: https://doi.org/10.30684/etj.v39i1A.571

This is an open access article under the CC BY 4.0 license http://creativecommons.org/licenses/by/4.0

\section{INTRODUCTION}

Recently, water resources in Iraq experienced deterioration in both quantity and quality. Due to the increase in urban growth and the increase in the population rate, treatment plants suffer from the ability to follow the increasing demand. Tigris and Euphrates rivers are the main water resources in Iraq. They also act as receiving bodies to the effluent water from municipal wastewater treatment plants of Iraqi cities and villages along these two rivers, especially in the villages where there are no wastewater treatment plants, which means disposing of the influent wastewater directly to the rivers. This situation necessitates a new wastewater treatment management strategy in the villages based on small scale decentralized wastewater treatment plants which are simple in operation and efficient in power consumption besides the effluent wastewater can be used for irrigation. Anaerobic wastewater 
treatment technology with simple post-treatment like polishing ponds may play a role in this strategy since the ambient temperature is above $20^{\circ} \mathrm{C}$ for more than eight months in Iraq.

The processes in which microorganisms break down by biodegradable in the absence of oxygen are called anaerobic digestion [1]. The anaerobic digestion process begins to start with bacterial hydrolysis of the microorganisms materials; the carbohydrates in the form of insoluble organic polymers are broken down to soluble derivatives that become obtainable for other bacteria [2]. Acidogenic bacteria transform the amino acids and sugars into ammonia, carbon dioxide, organic acids, and hydrogen.

These bacteria convert these subsequent organic acids into carbon dioxide, along with additional acetic acid, ammonia, and hydrogen. The final stage of this process are methanogens in which convert these products to carbon dioxide and methane [3]; by the methanogenic bacteria populations, it is considered a key role in wastewater treatments by anaerobic digestion [4]. Anaerobic digestion has been considered a promising method for the treatment of medium and high concentration wastewaters, due to the low generation of surplus sludge, the economy of the process, and the winning of the biogas as an alternative source of energy.

Anaerobic technology offers great promise, and the main factor makes it appropriate and less expensive [5]. Especially for developing countries that are usually located in regions, which the climate is hot most of the time and low temperatures don't remain for extended periods [6]. Anaerobic processes like a fluidized bed, anaerobic filter, expanded bed, and the Up-flow Anaerobic Sludge Blanket Reactor (UASB) with and without a three-phase separator has been applied to the treatment of domestic and industrial wastewater.

The UASB is the most typically used for high rate anaerobic treatment system [7], generally without moving mechanical parts, regulating both operating and capital costs [8]. Like high rate systems, they retain a high quantity of biomass in the form of granules, flocculants sludge, or aggregates of microorganisms. Besides, good contact between wastewater and biomass is ensured due to mixing due to biogas manufacture [7].

In moderately low strength such as sewage, the organic loading rate and hydraulic retention time HRT are the most important parameter determining the shape and the size of the UASB reactor [9]. Castillo et al.[10] examined the effect of different hydraulic retention time on a lab-scale Anaerobic Sludge Blanket Reactor of 750 1, fed with wastewater(temp. rang from 13 to $20 \mathrm{oC}$ and COD $=600$ $\mathrm{ppm}$ ). Their outcomes displayed that the COD's removal efficiency increased and achieved $66 \%$ due to the increase of the HRT. In an additional study, Alvarez et al. [11] studied the efficiency of a UASB reactor treating wastewater at a temperature of $14 \mathrm{oC}$ and an HRT of $11 \mathrm{~h}$. After an experimental period of 75 days, the removal efficiency was $41 \%$ for COD, $58 \%$ for TSS, and $54 \%$ for BOD5.

Because of the limited water resources in Iraq, there is a certain need for a cost-effective, appropriate technology for wastewater treatment; the UASB technology may be a typically attractive option because it can be used at a large or small scale at a lower cost, technically simple and the effluent water can be reused for irrigation purposes due to high ammonia and phosphor content.

This work's main objective was to investigate the feasibility of a pilot-scale Anaerobic Sludge Blanket Reactor UASB process as a post-treatment alternative for municipal wastewater treatment to simultaneously remove chemical oxygen demand (COD) and steady TSS with different organic load rate OLR.

\section{MATERIALS AND METHODS}

A graphic diagram of the UASB process conception is shown in Figure. 1 where influent is collected in the preparation tank and pumped by a submersible pump to the upper feeding tank from which the influent flow to the UASB reactor by gravity through-flow measurement device (flow meter). Gases from the UASB reactor pass through the water seal to prevent air from entering the reactor while the effluent exits from the top of the reactor to a collection tank. The other parameters including anaerobic sludge and influent wastewater and UASB reactor are as follows: 


\section{Anaerobic sludge}

Because there are no anaerobic wastewater treatment plants in Baghdad, anaerobic sludge was prepared in a 50-liter digester from aerobic sludge. The anaerobic sludge occurs in two steps. In the 1st stage, all received sludge flows are joint, and the mixture is heated to a minor temperature (about body temperature) to speed up biological conversion. The aerobic sludge was kept in the digester from 10 to 60 days with continuous and slow mixing. $10 \mathrm{~L}$ of synthetic wastewater, similar to that used in the UASB reactor, was fed to the digester every week. This is known as the stage of acid fermentation and proceeds rapidly. In the 2nd stage, known as the period of concentrated digestion, gasification, and stabilization, the more strong nitrogenous materials, such as the amino-acids and proteins, are attacked. The $\mathrm{pH}$ value requirement is kept from 6.8 to 7.4. The remaining solids are relatively stable can be used as aerobic sludge without creating objectionable conditions .

\section{II.Influent wastewater}

In the beginning, synthetic wastewater, at $\mathrm{pH} 7.8-8$, was prepared from municipal wastewater from Al- Zafrania residential complex with adding $2 \mathrm{~g} / \mathrm{L}$ Sodium acetate, $3 \mathrm{~g} / \mathrm{L}$ sugar, $0.4 \mathrm{~g} / \mathrm{L}$ Ammonium Chloride, and $0.8 \mathrm{~g} / \mathrm{L} \mathrm{KH} 2 \mathrm{PO} 4$ to get high strength organic wastewater. With time, the additives were reduced until municipal wastewater without additives was used at the end of this work. Elmitwalli et al. 2000 [12] stated this extended startup period as one of the key drawbacks of anaerobic treatment when seed sludge is not obtainable due to the low growth rate of methanogenic microorganisms. Generally, UASB is inoculated with an appropriate seed source to reduce startup time. This enables the Up-flow Anaerobic Sludge Blanket Reactor to work at dissimilar organic load range from $9 \mathrm{~kg}$ CODm-3day- 1 to $0.8 \mathrm{~kg}$ COD m-3day-1. Typical analytical data for the influent wastewater is displayed in TableI.

\section{III.UASB reactor}

UASB reactor consisted of a reaction zone $0.25 \times 0.25 \mathrm{~m}$ cross-sectional area with $3 \mathrm{~m}$ in height was made from transparent plastic. The evolved gas was delivered over a solution of $3 \mathrm{~N} \mathrm{NaOH}$ to grip CO2. Sludge height was kept at $(0.8 \mathrm{~m})$ depth and the reactor volume is $(180 \mathrm{~L})$ while the feeding flow rate was kept at $20 \mathrm{~L} / \mathrm{h}$ which means the hydraulic retention time HRT is $9 \mathrm{~h}$ and the upflow velocity is $0.4 \mathrm{~m} / \mathrm{h}$. The design upflow velocity is considered using the flow rate and inside diameter. In truth the volume full by sludge blanket granules acts as hydraulic dead space, denotation that the actual velocity of the liquid moving through the reactor can be slightly larger also the design strategies for liquid up-flow velocities in reactors point to that they must be $0.4-0.7 \mathrm{~m} / \mathrm{h}$ through normal flow situations and no more than $1.5 \mathrm{~m} / \mathrm{h}$ in peak flow [13].

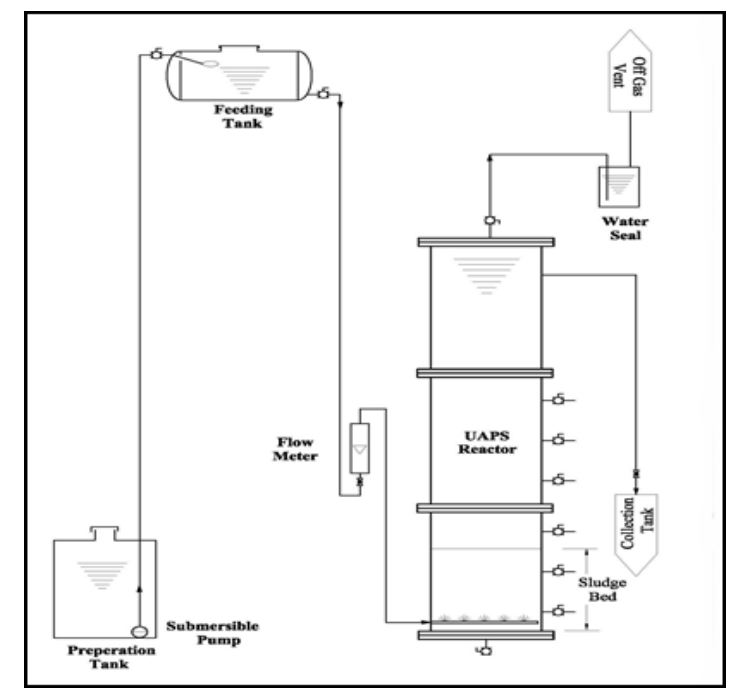

Figure 1: Schematic diagram of the UASB process. 


\section{IV.Analytical Techniques}

During the experimental study, influent and effluent were taken and the concentrations of Chemical oxygen demand COD was determined by the digestion method using the HACH spectrometer DR-3900. The concentration of total nitrogen (TN) and total phosphorus (TP) were determined by a persulfate digestion method and the persulfate UV oxidation method using HACH spectrometer DR-3900. Total suspended solids by the portable meter (Partech 740 monitor and solitech 10 sensors). The concentration of volatile fatty acids VFA was measured according to the standard methods $(5560 \mathrm{C})$ [14]. To determine the value of filtered Chemical oxygen demand (CODF) samples were filtered using a microfiber filter type Whatman GF/C glass.

\section{RESULTS AND DISCUSSION}

The temperature in the reactor during the working period $(20-30){ }^{\circ} \mathrm{C}$ which is lower than mesophilic digestion temperature $(30-38)^{\circ} \mathrm{C}[15]$ but it is not enough to cause any real impact on the performance as it was confirmed by [16].

Influent and effluent was measured by observing the values of COD, total and filtrated at different organic load, TSS removal efficiency at high and low influent TSS, effluent VFA, granulated solids $(3 \mathrm{~mm})$ and effluent $\mathrm{pH}$.

Fig. 2 shows the variation of organic load during the reactor-working period due to using nutrient additives with the municipal sewage in influent wastewater during the first 74 days after that only municipal sewage was used to the end of this work.

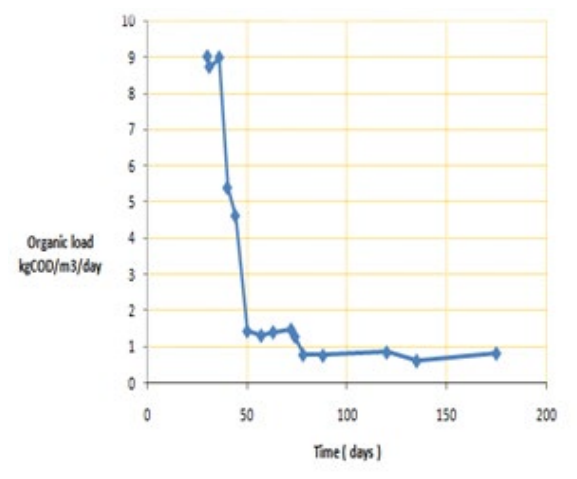

Figure 2: Variation of organic load with time

Fig. 3 demonstrates the removal efficiency of COD, total and filtrated, during the reactor, working period. It is clear that the removal is high during the first 74 days, $86 \%$ as maximum and $70 \%$ as a minimum while in the time after that, it ranges between $74 \%$ to $45 \%$, this fall in removal efficiency due to decreasing in organic load [2]. The removal efficiency for filtrated COD is lower than in total COD during the working time, this may be because of some COD is as organic suspension particles which are removed in the reactor as suspension These findings agree with Leitao et al.2005[17].

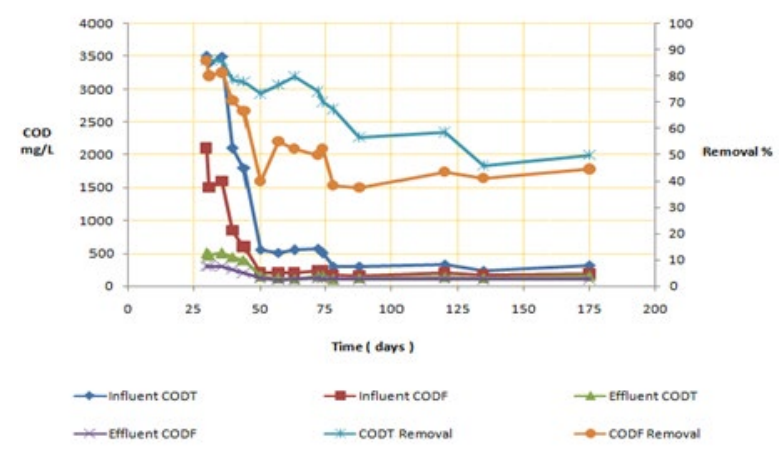

Figure 3: Variation of COD removal with time 
Fig. 4 show the total suspension removal with time, the efficiency is moderately high between $(67-70) \%$, most of the suspension is removed in the filtration process through the wastewater flow in the sludge bed, another removal occurs due to settlement of the slow up flow in the reactor.

Fig. 5 illustrates the $\mathrm{pH}$ of the effluent wastewater in the UASB reactor. From Fig. 5 the $\mathrm{pH}$ range was reached 8.15-8.0 for influent and 8.4-8.3 for effluent. It was observed a small increase in the effluent $\mathrm{pH}$ and this is due to the conversion of total Nitrogen to Ammonia in the reactor and this is a normal work by anaerobic reactors to treating wastewater .

The effluent $\mathrm{pH}$ values were found above the neutral limit (7.0), resulting in a good rank of the UASB and no acidification harms has happened.

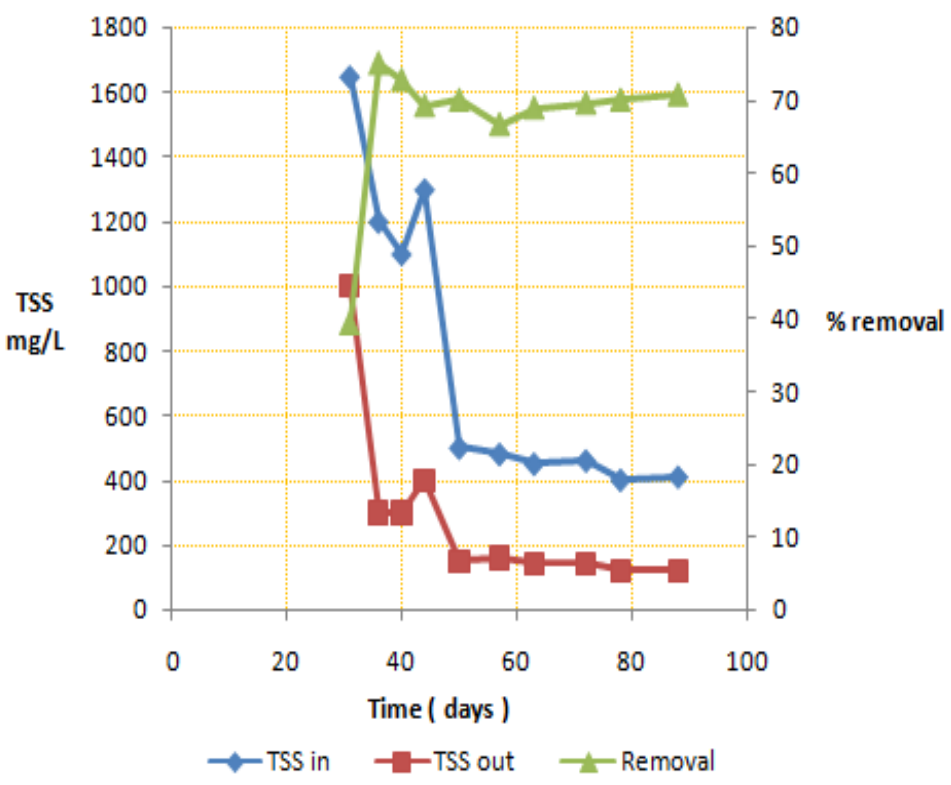

Figure 4: Variation of TSS removal with time

The observation of VFA is one of the most key factors for the UASB reactor control during process condition because VFA is reflected as an indicator of the process competence of COD translation to methane. With increase VFA, a part of COD transformed by acidification phases, hydrolysis, and not completely converted by methanogens phase to methane but still in the form of VFA. On the other hand, If VFA increased, the $\mathrm{pH}$ decreased to the acidic point, which means inhibits the progression and the reactor will be failed [18].

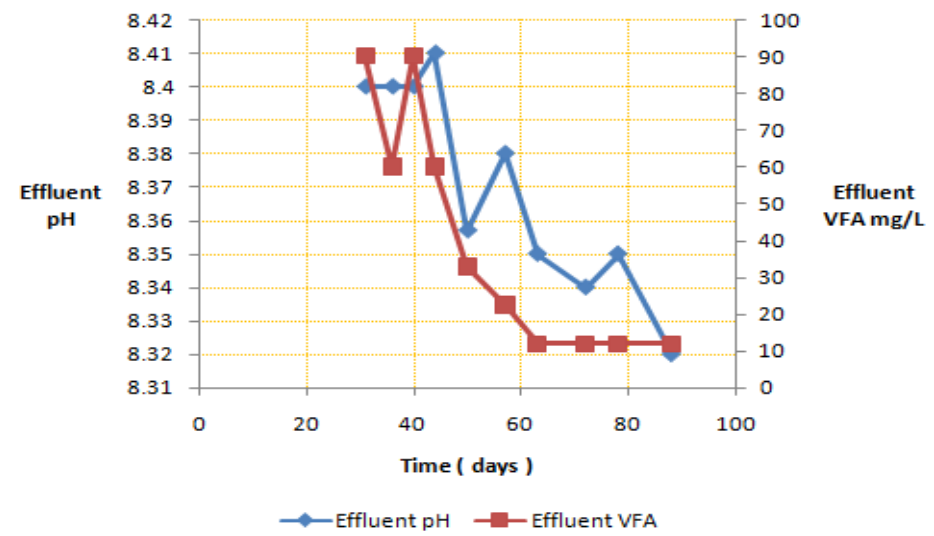

Figure 5: Variation of effluent $\mathrm{pH}$ and VFA with time 
Table I: Typical composition of influent sample

\begin{tabular}{ccc}
\hline \hline Parameter & Max. mg/L & Min. $\mathbf{~ m g / L ~}$ \\
\hline CODT $^{*}$ & 3510 & 320 \\
CODF $^{*}$ & 2100 & 180 \\
TN & 100 & 50 \\
TP & 12 & 8 \\
TSS & 1650 & 410 \\
Alkalinity as CO3 & 1200 & 600 \\
pH & 8.2 & 7.5 \\
\hline
\end{tabular}

*CODT Total COD, CODF Filtrated COD

\section{CONCLUSION}

A pilot-scale of UASB performance estimate in steady-state conditions to treat wastewater effluent, showing the efficiency of COD removal was $85 \%$ to $45 \%$ depending on the influent organic load and for the temperature ranges $20-30^{\circ} \mathrm{C}$. Total suspended solids removal efficiencies were $70 \%$ to $75 \%$ which shows the total suspended removal is not affected by influent organic load since the velocity was saved constant at $0.4 \mathrm{~m} / \mathrm{h}$ through the steady-state phase. This can be explained as a flow that may be returned to the accumulation of excess sludge and solids in the UASB reactor, which works as a screen, impede the solid movement and retain back in the reactor. The effluent $\mathrm{pH}$ and effluent VFA concentration values were around 8.4 to 8.2 and 90 to $14 \mathrm{mg} / \mathrm{L}$ respectively at the steady-state phase. The positive difference of alkalinity and the low discharge concentrations of volatile fatty acids together with observed by alkaline $\mathrm{pH}$ values established that there was no risk of acidification at an experimental run at different temperatures rang of $20-30^{\circ} \mathrm{C}$. The pilot plant of UASB reactor results indicates that the wastewater can be used for irrigation purposes after the water purification process (such as sedimentation, polishing pond, flocculation, facultative/aerobic ponds disinfection, filtration, etc.) due to their nutrient content $(\mathrm{N}, \mathrm{P})$. To obtain treated wastewater at a low cost, it is recommended that facultative/aerobic ponds, natural polishing ponds, or filtration methods can be used as a post-treatment of the Up-flow Anaerobic Sludge Blanket Reactor UASB.

\section{References}

[1] P. Fongastikul, D.S. Mavinic and A. Lo., A two phase anaerobic digestion: Concept, process failure and maximum system loading rate, Water. Environ. Res., 66(1994) 243-254. https://doi.org/10.2175/WER.66.3.10

[2] W. Brummeler, L. Hulshoff, J. Dolfing, G. Lettinga, and A. Zehnder, Methanogenesis in an Upflow Anaerobic Sludge Blanket Reactor at $\mathrm{pH} 6$ on a Acetate propionate mixture and Environm, Microbiology, 49(1985)1472-1477. https://doi.org/10.1128/aem.49.6.1472-1477.1985

[3] P. Hulshoff, and G. Lettinga, New technologies for anaerobic wastewater treatment, Wat. Sci. Technol., 18(1986) 41-53.

[4] T. Meisam, A. R. Raha, G. André-Denis,Y. Wright,S. Alawi, S. Kenji and A. Mohd, Importance of the methanogenic archaea populations in anaerobic wastewater treatments, Process. Biochem., 45(2010) 12141225. http://dx.doi.org/10.1016/i.procbio.2010.05.017

[5] E. Foresti, Anaerobic treatment of domestic sewage: established technologies and prospectives, 9th International Symposium on Anaerobic Digestion, Antwerpen, Belgium 2001.

[6] A. Tawfik, F. El-Gohary, H. Temmink, Treatment of domestic wastewater in an up-flow anaerobic sludge blanket reactor followed by moving bed biofilm reactor, Bioprocess. Eng. , 33(2010) 267-276. https://doi.org/10.1007/s00449-009-0321-1

[7] E. Behling, A. Diaz and G. Colina, Domestic wastewater treatment using UASB reactor, Bioresour. Technol., 61(1997) 239-245. https://doi.org/10.1016/S0960-8524(97)00148-X

[8] K. Kalash, M. Kadhom, M. Al-Furaiji, Short-Cut Nitrification of Iraqi Municipal Wastewater for Nitrogen Removal in a Single Reactor, Mater. Sci. Eng. C ., 518(2019)1-7, 2019. https://doi.org/10.1088/1757899X/518/2/022024

[9] A. Azimi and M. Zamanzadeh, Determination of design criteria for UASB reactors as a wastewater pretreatment system in tropical small communities, Int. Environ. Sci. Tech., 1(2004) 51-57.

[10] A. Castillo, F. Cecchi, AL.Mata, A combined anaerobic-aerobic system to treat domestic sewage in coastal areas, Water. Res., 31(1997)3057-3063. https://doi.org/10.1016/S0043-1354(96)00064-4 
[11] A. lvarez, A. rmstrong, M.Go mez, Anaerobic treatment of low-strength municipal wastewater by a twostage pilot plant under psychrophili conditions, Bioresour. Technol., 99(2008) 7051-7062. https://doi.org/10.1016/j.biortech.2008.01.013

[12] T. Elmitwalli, K. Oahn, G. Zeeman, Treatment of domestic sewage in a two-step anaerobic filter/anaerobic hybrid system at low temperature, Water. Res., 36(2002)2225-2232. https://doi.org/10.1016/s0043-1354(01)00438-9

[13] C. Chernicharo, Anaerobic Reactors. Volume 4, biological wastewater treatment Series, , IWA Publishing, UK 2007.

[14] S. Lenore, E. Arnold, R. Rhodes, Standard Methods for the Examination of Water and Wastewater, American Health Association 17th Edition 1989.

[15] R. Leitao, F. Silva-Filho, J. Sanders, W. van Haandel, A.C.; Zeeman, G.; Lettinga, G. The effect of operational conditions on the performance of UASB reactors for domestic wastewater treatment, Water Sci. Technol., 52(2005) 299-305.

[16] Y. Song, S. Kwon, J. Woo, Mesophilic and thermophilic temperature co-phase anaerobic digestion compared with single-stage mesophilic- and thermophilic digestion of sewage sludge, Water. Res. J., 38(2004) 113-118. https://doi.org/10.1016/j.watres.2003.12.019

[17] M. Henze, and P. Harremose, Anaerobic treatment of wastewater in fixed film reactors, Water. Sci. Technol., 15(1983) 1-101. http://dx.doi.org/10.2166/wst.1983.0161

[18] S. Sayed, M. Fergala, Two-stage UASB concept for treatment of domestic sewage including sludge stabilization process, Water. Sci. Technol., 32(1995)55-63. https://doi.org/10.2166/wst.1995.0402 